\title{
Rendahnya Keterpilihan Perempuan pada Pemilu 2019 di Bali
}

\section{Ni Made Ras Amanda Gelgel ${ }^{1}$ dan Kadek Dwita Apriani ${ }^{2}$ \\ ${ }^{1}$ Universitas Udayana, ${ }^{2}$ Universitas Indonesia \\ Email: rasamanda13@unud.ac.id}

\author{
Abstract \\ The Low Representation of Women in the 2019 \\ Legislative Election in Bali
}

The results of the post-reform until the 2019 directelection showed that Bali had never succeeded in sending female representatives to the Indonesian Parliament. This paper discusses causes of the lackness of women candidates who succeced to gain chair in the national parliament. The paper uses supply-demand framework from Norris dan Lovenduski with qualitative method research. Demand side sees how political parties in Bali selected women to be their candidates discriminatively and not giving the same access to them. Supply side sees that women candidates in Bali get obstacles and constrains in various aspects such as (1) minimum financial ability, (2) lack of political experiences, (3) limited social networks, (4) limited time and space, (5) lack of motivation in political carrier. These cause an outcome of the lackness of women candidates being elected in the election.

Keywords: Bali, election, politic, supply-demand, women

Abstrak
Hasil pemilu langsung pascareformasi hingga Pemilu 2019
menunjukkan Bali tidak pernah berhasil mengirimkan wakil
perempuan ke DPR RI. Tulisan ini membahas mengenai apa
yang menyebabkan kegagalan perempuan Bali dalam merebut
kursi di DPR RI dengan menggunakan kerangka Supply-
Demand. Pada sisi demand yang menitikberatkan pada
bagaimana partai politik menyeleksi bakal calon untuk masuk
ke dalam daftar caleg diketahui bahwa partai politik memberi
perlakuan yang berbeda dari sisi akses ke mesin partai pada
kandidat laki-laki dan perempuan. Pada sisi supply, penelitian
ini menemukan bahwa caleg perempuan yang bertarung di
Bali pada Pemilu 2019 memiliki keterbatasan dan hambatan di
berbagai aspek seperti (1) kemampuan finansial yang minim,


(2) pengalaman politik yang sedikit, (3) jaringan sosial yang terbatas, (4) keterbatasan ruang gerak dan waktu serta, (5) rendahnya motivasi politisi perempuan dalam berkarir politik. Perpaduan diskriminasi partai dan hambatan-hambatan besar pada sisi supply ini menyebabkan outcome berupa rendahnya keterpilihan perempuan di Bali pada pemilu 2019.

Kata kunci: Bali, pemilu, perempuan, politik, supply-demand

\section{Pendahuluan}

Drovinsi Bali selama Pemilu langsung di Indonesia, 1999-2019, 1 tidak pernah berhasil mengirimkan perempuan sebagai anggota legislatif di tingkat nasional. Hal ini menunjukkanbahwa masyarakat Bali kurang memberikan kepercayaan kepada perempuan untuk duduk di DPRRI. Tulisan ini mengeksplorasi mengenai faktorfaktor yang mempengaruhi rendahnya keterpilihan perempuan di Provinsi Bali dengan menggunakan framework teori Supply-Demand.

Harapan agar partai besar seperti PDIP bisa meloloskan perempuan untuk duduk di DPRRI ternyata tidak pernah terwujud. Pada Pemilu 2019, dari sembilan calon legislatif untuk DPRRI dari PDIP, enam lolos ke Pusat tetapi keenamnya adalah laki-laki, tidak ada satu pun yang perempuan. Bali memang selalu menjadi provinsi dengan persentase kursi perempuan kurang dari 10 persen di tingkat DPRD provinsi di seluruh Indonesia. Untuk hasil Pemilu 2009 dan 2014, dari 34 provinsi, Provinsi Bali selalu berada di posisi lima terendah persentase kursi perempuan di tingkat DPRD Provinsi (Tabel 1).

Tabel 1. Persentase Kursi Perempuan di DPRD Provinsi Bali Periode 2009,2014

\begin{tabular}{lll}
\hline Tahun & $\mathbf{2 0 0 9}$ & $\mathbf{2 0 1 4}$ \\
\hline Kursi perempuan & 4 & 5 \\
Total kursi & 55 & 55 \\
Prosentase & 7,27 & 9,09 \\
\hline & & \\
\hline Rangking & 5 terendah & 3 terendah \\
DPRD lainnya & Nusa Tenggara Timur $(5,56 \%)$ & Papua Barat $(2,22 \%)$ \\
& Aceh $(5,80 \%)$ & Maluku Utara $(8,89 \%)$ \\
& Maluku Utara $(6,67 \%)$ & \\
& Papua $(7,14 \%)$ & \\
\hline
\end{tabular}

Sumber: Diolah dari Buku Cakra Wikara Indonesia 2018 
Meskipun angka partisipasi perempuan dari dapil Bali ke tingkat nasional minim, namun persentase perempuan di DPRD tingkat Provinsi dan Kabupaten di Bali menunjukkan perubahan setiap pemilu. Perubahan angka persentase dapat dilihat pada Tabel 2 di bawah ini:

Tabel 2. Prosentase Perempuan di DPRD Provinsi/Kota/Kabupaten di Bali

\begin{tabular}{llll}
\hline Tahun Pemilu & $\mathbf{2 0 0 9}$ & $\mathbf{2 0 1 4}$ & $\mathbf{2 0 1 9}$ \\
\hline Jumlah Perempuan & 31 & 32 & 52 \\
\hline Total Kursi & 405 & 405 & 405 \\
\hline & & & \\
Prosentase & 7,65 & 7,90 & 12,8 \\
\hline
\end{tabular}

Sumber: Diolah dari beberapa sumber 2019.

Tabel 2 menunjukkan peningkatan jumlah persentase perempuan pada legislatif di Bali. Inter-Parliamentary Union (IPU) dan UN Women mengeluarkan laporan dalam Women in Politics 2017 Map bahwa terjadi stagnansi pada jumlah perempuan yang duduk di parlemen dan pemerintahan. Perdana dan Wildianti (2019) menyatakan setelah 20 tahun lewat reformasi, pencapaian perempuan di dunia politik di Indonesia masih stagnan dan masih menjadi tugas besar untuk merangsang perempuan muda tertarik politik. Amalia (2019) menuliskan bahwa perempuan kerap kali hanya dijadikan objek pemilu yang dijadikan untuk meraup suara.

Berdasarkan Pemilu 2009, Indonesia tercatat menduduki ranking ke-113 dunia dengan persentase perempuan sebesar 18,2 persen atau setara dengan 102 dari total 560 anggota DPR RI (Manalang, 2018). Jumlah perempuan di parlemen Indonesia meningkat pada tahun 2004 menjadi 11,7\%. Pada 2009 menjadi $18.2 \%$, dan menurun tipis menjadi 17,3\% pada tahun 2014. Persentase perempuan di DPR RI kembali meningkat dari hasil Pemilu 2019. Dari 575 anggota DPR RI terpilih, tercatat 117 orang (20,03\%).

Bali dengan budaya dan adatnya membuat perempuan memikul tiga beban (Nakatani 2003). Pertama adalah beban 
domestik atau rumah tangga. Kedua adalah beban publik atau masyarakat dan ekonomi. Ketiga ada beban adat termasuk ritual adat dan ritual keagamaan. Perempuan Bali melaksanakan ritual adat dan keagamaan dengan beberapa alasan. Ritual keagamaan adalah implementasi ritual sebagai persembahan pada Tuhan serta leluhur. Kegiatan ritual keagamaan juga menjadi penting untuk keberlangsungan hidup keluarga dan menjaga posisi sosial rumah tangga mereka di dalam komunitas (Nakatani, 2003).

Perempuan Hindu Bali tidak terlatih untuk pengambilan keputusan atau terlibat dalam pengambilan keputusan di tingkat masyarakat. Unit pengambilan keputusan terkecil di tingkat desa adat di Bali berada pada tingkat banjar (Rhoads, 2012). Banjar secara tradisional berdasar pada hukum adat dan bertanggungjawab pada proses ritual, namun perempuan tidak diberikan kesempatan untuk bersuara di banjar di Bali (Warren, 2007 dalam Rhoads, 2012). Riset Kindon (1998, yang dikutip Nitish Jha 2004) menjelaskan bahwa laki-laki Bali sangat jarang mengkonsultasikan apa yang diputuskan di sangkep banjar dengan istrinya, meski keputusan tersebut berdampak pada pekerjaan adat yang harus dikerjakan perempuan. Namun Darma Putra (2007) mengungkapkan Bali telah memandang perempuan penting untuk duduk di legislatif sejak lama. Data menunjukkan tiga perempuan yang duduk di DPRD pada awal 1950-an. Hal ini menunjukkan adanya penghormatan dan kemajuan atas perempuan di bidang politik (Darma Putra, 2007:106).

\section{Metode}

Penelitian ini merupakan kajian kualitatif dengan dengan terknik pengumpulan data melalui wawancara dan observasi. Wawancara dan observasi dilakukan selama masa menjelang dan setelah Pemilu serentak tahun 2019. Teknik penentuan informan dilakukan dengan non-probability sampling purposive di mana informan terpilih adalah informan dengan kriteria khusus yang mampu menjawab permasalahan (Neuman, 2014:278). Wawancara dilakukan terhadap 17 narasumber, 12 di antaranya adalah caleg perempuan, dan 4 pengurus partai politik di tingkat provinsi Bali, 
dan 1 orang merupakan tokoh Gerakan perempuan di Bali. Adapun jumlah narasumber dari masing-masing partai politik, adalah 5 orang caleg perempuan dari PDIP, masing-masing satu orang caleg perempuan dari partai Demokrat, Nasdem dan Gerindra, masingmasing dua orang dari Partai Golkar dan PSI. Narasumber yang berasal dari partai politik berjumlah empat orang, dua orang dari PDIP dan masing-masing satu orang dari Nasdem dan Gerindra.

Model supply-demand dikemukakan oleh Norris dan Lovenduski (1995) yang digunakan sebagai adalah kerangka berpikir analitis untuk memahami faktor-faktor yang mempengaruhi proses seleksi dalam kontestasi politik. Hasil sebuah pertarungan atau outcome adalah cerminan dari sisi demand apa yang diinginkan oleh partai politik atau siapa yang diinginkan partai politik untuk ikut bertarung.

Sisi demand berasumsi, partai atau tokoh partai yang memilih kandidat untuk berpolitik tergantung pada penilaiannya terhadap bakal calon legislatif. Mona Lena Krook (2009) mengungkapkan banyak faktor yang termasuk dalam proses evaluasi bakal calon legislatif oleh partai, seperti penilaian karakter secara personal, kualifikasi formal, dan pengalaman politik. Diskriminasi yang dimaksudkan Norris adalah penilaian kepada individu berdasarkan karakteristik kelompoknya. Praktik ini dibagi dua, direct dan imputed discrimination. Diskriminasi langsung (direct) adalah penilaian negatif atau positif terhadap seseorang berdasarkan pada karakteristik yang terlihat dalam kelompoknya, bukan melihat sosok tersebut secara invidu terpisah. Imputed discrimination adalah praktik yang dilakukan partai atau selectors dalam antisipasi reaksi pemilih atas kelompok sosial tertentu. Bias sosial pada umumnya terjadi dalam proses ini.

Sisi Supply menjelaskan bahwa outcomes merefleksikan motivasi/keinginan caleg untuk memiliki/mengejar karir politik, berkarir di politik. Menurut Norris dan Lovenduski (1995) supplyside memiliki hambatan dan halangan yang dibagi dalam dua dimensi yakni hambatan sumber daya dan hambatan motivasi. Hasil penelitian Norris dan Lovenduski (1995) di Inggris Raya menuliskan 
perempuan yang ingin terjun dalam politik akan menghadapi beberapa halangan dan hambatan, yakni hambatan sumberdaya seperti waktu, uang, jaringan pendukung dan pengalaman serta hambatan motivasi seperti tidak adanya dorongan, ambisi dan ketertarikan pada politik.

\section{Pembahasan}

\subsection{Perempuan dan Pemilu di Indonesia}

Di Indonesia tidak pernah ada perbedaan antara laki-laki dan perempuan dari sisi hak pilih. Sejak pemilu 1955 dilaksanakan, perempuan telah memiliki hak pilih, sama dengan laki-laki. Perbedaan antara laki-laki dan perempuan baru terlihat pada hasil pemilu. Bias sosial di parlemen Indonesia sangat kentara. Hal ini baru mendapat perhatian pada masa reformasi dengan sistem afirmasi sehingga semakin bertambah jumlah perempuan duduk di legislatif, walaupun jumlah itu terus diharapkan meningkat (Foto 1).

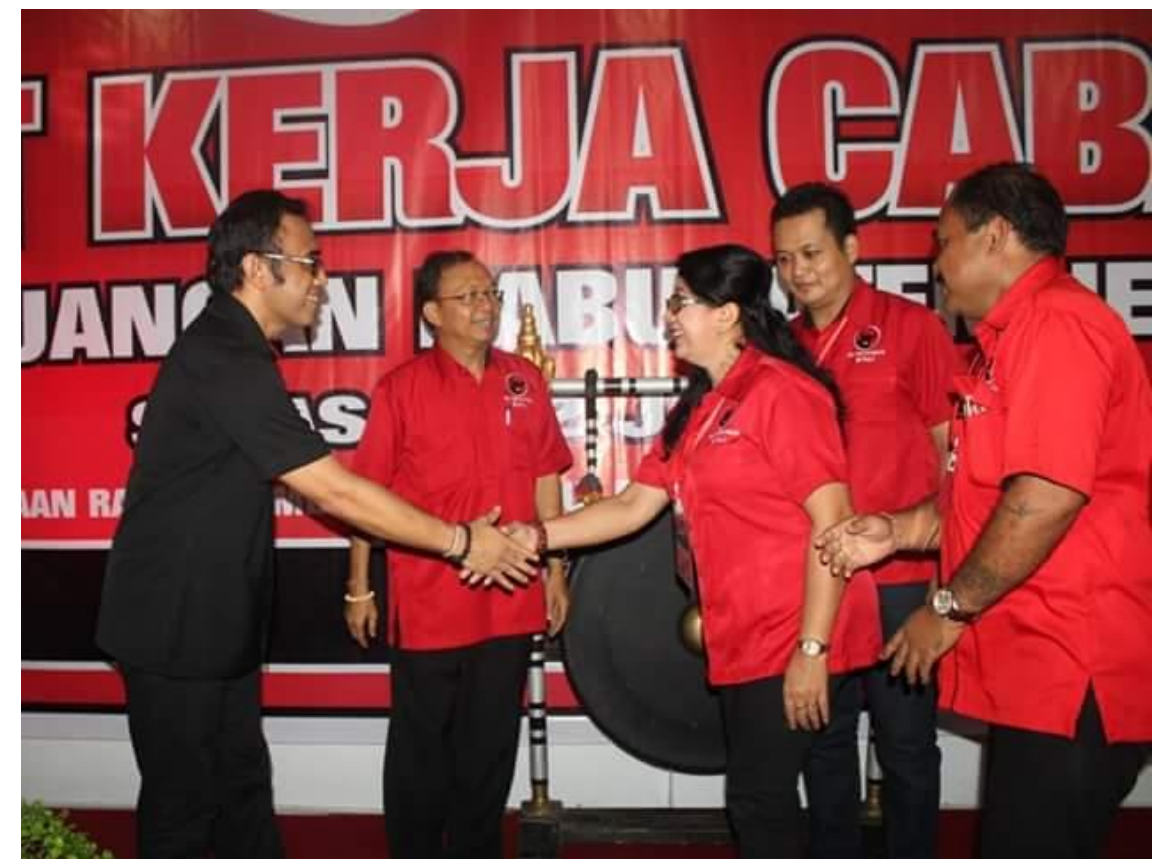

Foto 1. Politisi perempuan, Ni Made Sri Sutharmi, berhasil menjadi Ketua DPRD Jembrana, Bali (Foto Dokumen Sri Sutharmi). 
Istilah afirmasi dengan kuota perempuan pada daftar calon baru dikenal di Indonesia menjelang pemilu 2004 dan mulai diaplikasikan dengan UU Pemilu No.12/2003. Pasal 65 dalam menyebutkan "setiap partai politik peserta pemilu dapat mengajukan calon legislatif untuk setiap daerah pemilihan dengan memperhatikan keterwakilan perempuan sekurang-kurangnya 30 persen". Hal ini membuka kesempatan bagi perempuan dengan memaksa partai politik untuk merekrut dan mencalonkan perempuan dalam daftar calon pemilu legislatif. Hasilnya, setengah dari partai politik peserta pemilu 2004 menempatkan 30\% perempuan dalam daftar calon legislatifnya. Namun, tidak adanya sanksi membuat kebijakan afirmasi tidak efektif. Aturan terkait afirmasi ini mendapat penyempurnaan kembali pada pemilu tahun 2009 melalui paket UU politik untuk Pemilu 2009 (Cakra Wikara Indonesia, 2018).

Ketentuan kuota perempuan dalam daftar calon anggota legislatif pada pemilu tahun 2014 sama dengan ketentuan pada pemilu 2009, namun diperkuat dengan PKPU No 7/2003 yang mewajibkan pencalonan perempuan sebagaimana diatur dalam UU untuk dilakukan di semua Dapil. Bali sebagai salah satu wilayah di Indonesia tunduk pada aturan afirmasi tersebut. Penerapan afirmasi memperlihatkan hasil pada tingkat lokal, namun tidak pada keterwakilan perempuan dari Dapil Bali di DPR RI. Keterpilihan perempuan dari Dapil Bali tetap nihil sejak tahun 2004 hingga tahun 2019. Pada periode 2014-219 terdapat dua anggota DPR RI perempuan dari Dapil Bali, namun keduanya merupakan Pengganti antar waktu (PAW). Prastiwi dan Haliim (2018) menekankan keterlibatan perempuan di legislatif dan partai politik akan membantu perempuan memiliki posisi yang semakin menguat dan bangkit dari jerat elit-oligarki.

\subsection{Hasil Pemilu 2019 di Bali}

Pada pemilu 2019, persentase perempuan yang menduduki kursi parlemen di seluruh DPRD Provinsi, Kota dan Kabupaten di Bali meningkat dibandingkan Pemilu 2014. Berdasarkan hasil 
rekapitulasi penghitungan suara Pemilu 2019, sebanyak 54 calon legislatif (caleg) perempuan yang lolos di DPRD tingkat provinsidan kabupaten/kota.

Data KPU Provinsi Bali menunjukkan, pada tingkat DPR RI, dari sembilan yang mewakili Bali, terdiri dari 6 dari PDIP, 2 dari Golkar, dan 1 dari Demokrat. Kesembilan calon terpilih ini adalah laki-laki, tidak ada satu pun perempuan. Pada tingkat DPRD Provinsi, terdapat 9 perempuan, yakni dari 6 dari PDIP, dan masing-masing 1 orang dari Golkar, Demokrat, dan PSI. Berikut adalah tabel perkembangan kursi legislatif yang berhasil diraih politisi perempuan dari Pemilu 2009, 2014 hingga data pemilu 2019.

Tabel 3. Perkembangan Kursi Legislatif Politisi Perempuan Pada Pemilu 2009, 2014, 2019

\begin{tabular}{lllll}
\hline \multirow{3}{*}{ Provinsi } & & 2009 & 2014 & 2019 \\
\cline { 3 - 5 } & Babupaten & 4 & 5 & 9 \\
\cline { 3 - 5 } & Denpasar & & & \\
Tabanan & 1 & 1 & 2 \\
Jembrana & 2 & 3 & 9 \\
Buleleng & & 4 & 7 \\
& Karangasem & 6 & 6 & 8 \\
Klungkung & 5 & 3 & 2 \\
Gianyar & 2 & 5 & 6 \\
Bangli & 2 & 3 & 2 \\
Badung & 3 & 1 & 3 \\
& & 3 & 1 & 64 \\
\hline Total & 4 & 32 & \\
\hline
\end{tabular}

Sumber: diolah dari berbagai sumber

\subsection{Supply-Side}

Karakteristik caleg perempuan secara umum di Indonesia selama ini seringkali dipandang kurang memenuhi syarat. Soeseno (2014) dalam artikelnya memandang pesimis para perempuan yang duduk di legislatif periode 2014/2019. Ia menilai perempuan yang 
lolos duduk sebagai anggota dewan adalah para pencari kerja yang tidak merepresentasikan kepentingan perempuan, tidak cukup peka pada isu-isu perempuan di masyarakat.

Secara umum caleg perempuan di Bali memiliki karakteristik tingkat pendidikan yang cukup beragam, tidak memiliki modal finansial yang cukup, strategi yang digunakan adalah hubungan sosial/ jaringan, sebagian besar bukan kader partai, memiliki relasi kekuasaan, berasal dari keluarga yang telah lama berkecimpung dalam partai, memiliki kecenderungan tidak cukup aktif di adat, dan tidak memiliki motivasi yang cukup untuk berpolitik. Dewi dkk (2008 mengutip Lin 2001) dan Burt (1995) menjelaskan konsep modal dalam sebuah kompetisi politik, yakni modal manusia, finansial dan jaringan. Razavi (2001) menegaskan permasalahan perempuan dalam berpolitik adalah akibat sosial budaya yang partriarki. Berikut uraian sumber daya dan motivasi yang dimiliki politisi perempuan di Bali.

\subsubsection{Sumber daya finansial}

Sumber daya finansial menurut Norris dan Lovenduski (1995) menjadi faktor yang penting dalam proses politik. Finansial atau kekuatan modal uang dibutuhkan untuk proses berpolitik. Uang dibutuhkan pada setiap tahapan, mulai saat pencalonan, kampanye, proses pemilihan, hingga proses karir dalam politik (Norris, 1995).

Pada perempuan politik di Bali, sumber daya finansial yang dimilikinya sangat terbatas. Bahkan beberapa perempuan yang kami wawancarai mengatakan tidak memiliki modal finansial sama sekali.

Salah seorang yang tidak memiliki cukup modal uang adalah Veronica dari Partai Solidaritas Indonesia Dapil Denpasar. Ia mengatakan bergabung dengan partai politik dikarenakan partainya tidak mewajibkan iuran atau berbayar.

"Bagus ini PSI, gak perlu bayar karena saya kan gak punya duit"

"Saya tidak membentuk timses, karena satu adalah masalah dana.. saya tidak punya uang untuk buat baliho dan kartu nama"- (Wawancara Veronica 
Meity Karundeng, caleg DPRD Kota Denpasar, PSI , 28 Maret 2019).

Ia menilai uang menjadi sangat penting dalam proses berpolitik terutama dalam proses pemilu. Praktik-praktik politik uang yang diduga dilancarkan oleh lawan politik lainnya membuat politisi perempuan yang minim sumber daya finansial semakin tidak dapat bergerak. Bentuk praktik politik uang beragam, mulai dari bentuk sumbangan ke tingkat banjar hingga serangan fajar.

"Saya khawatir digempur serangan fajar (dari caleg lain) berapa angkanya saya tidak tahu"- (Wawancara Anak Agung Istri Putri Astrid Kartika, caleg DPR RI, PDIP, 29 Maret 2019).

Bentuk lainnya dari praktik politik uang adalah dengan memanfaatkan bantuan sosial yang kewenangannya dimiliki anggota legislatif. Untuk perempuan yang telah duduk di DPRD, dukungan finansial dari bansos atau bantuan sosial pun dinilai cukup efektif, namun masih terbatas dibandingkan kekuatan finansial lain yang dimiliki lawan politiknya terutama yang lakilaki. Hal ini ditegaskan Komang Kisid, tim sukses dari Yuli, politisi golkar incumbent yang kembali bertarung dalam pemilu 2019.

"Memanfaatkan Bansos Reses dan cukup efektif mempertahankan kepercayaan konstituen, karena pengaruh bansos cukup signifikan di masyarakat... Sekaa Gong bisa disupport dengan bantuan baju batik dari kegiatan reses, hibah dan bansosnya" - (Wawancara Komang Kisid, Tim Sukses Ni Putu Yuli Artini, DPRD Provinsi Dapil Karangasem, Golkar, 4 April 2019).

Perempuan politisi di Bali pun mengakui bahwa masyarakat di Bali semakin pragmatis. Bahkan tidak sedikit politisi yang membutuhkan biaya politik dan kampanye hingga milyaran rupiah, sehingga terjebak di dalam putaran hutang.

"Untuk modal, astungkara selama kampanye tidak banyak yang keluar, dan saya tidak minta suami dan saya sudah bisa menabung dari pengahasilan 
saya selama ini... kampanye saat ini telah semakin pragmatis, astungkara saya tidak sampai ke sana ke sini pinjam uang" - (Wawancara IGA Diah Werdhi Srikandi, Caleg DPRD Provinsi, Dapil Jembrana, PDIP, 30 Maret 2019).

Sumber daya finansial atau keuangan menjadi hambatan bagi politisi perempuan di Bali. Ada pun perempuan petahana, akses dan kewenangan untuk menyalurkan bansos sebagai sumber daya finansial pun terbatas.

\subsubsection{Sumber daya waktu}

Menjadi seorang politisi dituntut beragam aktivitas yang menghabiskan waktu untuk kegiatan-kegiatan politik. Kegiatan politik yang dilakukan di antaranya adalah kehadiran dalam beragam rapat partai, pertemuan-pertemuan sosial, kegiatan penggalangan dana, dialog bersama konstituen, penyebaran pesan politik, hingga safari kampanye dari satu titik ke titik lainnya (Norris dan Lovenduski, 1995: 155-156). Masa kampanye yang panjang pada Pemilu 2019 di Indonesia menuntut politisi perempuan meluangkan waktu yang cukup banyak. Politisi perempuan yang berada di bawah partai juga harus mengikuti jam kerja partai politik yang cenderung tidak ramah pada perempuan.

"rapat-rapat penting dalam partai biasanya berlangsung pada malam hari hingga dini hari, ini menyulitkan pada perempuan yang memiliki tanggungjawab juga pada rumah tangga dan anak-anak" - (Wawancara Luh Riniti Rahayu, LSM Bali Sruti, Pemerhati Perempuan di Bali, 19 Juli 2019).

Hal ini pula yang menyulitkan kaderisasi politisi perempuan di tingkat partai politik. Perempuan di Bali memiliki banyak beban yakni beban publik, beban domestik, serta beban adat. Beban ini menyebabkan minimnya waktu perempuan tersebut untuk dapat berkonsentrasi pada karir politiknya. Hal ini disampaikan Veronica dari Partai Solidaritas Indonesia. 
"sulit mencari kader perempuan, giliran masih mahasiswa mereka harus kuliah dan tergantung pada orangtua, giliran bekerja, waktunya habis harus mengurus suami, banten (perangkat upacara), gitu-gitu"- (Wawancara Veronica Meity Karundeng, caleg DPRD Kota Denpasar, PSI, 28 Maret 2019).

Pascamenikah, beban bagi perempuan Bali lebih tinggi, mereka terikat tidak hanya oleh keluarga tapi terikat pula dengan aturan di Desa Adat. Beban di desa adat kerap menyita waktu. Di sisi lain politik membutuhkan pengorbanan waktu yang banyak. Kampanye yang mewajibkan kehadiran di setiap kesempatan pun kerap kali berbenturan dengan kewajiban di desa adat atau kegiatan kekerabatan lainnya.

"Waktu mengingat ketika sudah menikah harus mengurusi suami dan anak, harus pintar membagi waktu karena di politik itu tidak tentu" - (Wawancara I Gusti Ayu Diah Werdhi Srikandi W Caleg DPRD Provinsi, Dapil Jembrana, PDIP, 30 Maret 2019).

Waktu dan ruang gerak yang terbatas pun menjadi halangan dan hambatan politisi. Aktivitas partai politik yang biasa berlangsung pada malam hari dan pentingnya waktu kunjungan kepada konstituen membuat ruang gerak politisi perempuan menjadi terbatas. Norris dan Lovenduski (1995) menyatakan dalam berkarir politik, hal yang harus dikorbankan adalah waktu. Namun, bagi perempuan di Bali, hal yang dikorbankan selain waktu juga ruang gerak yang terbatas akibat persepsi masyarakat akan perempuan. Hambatan ini yang tidak dihadapi politisi lakilaki.

"Kalau orang laki-laki di mana-mana, berkunjung sampai jam 02.0003.00 melakukan lobby-lobby berkunjung ke pemilih. Dalam pemilihan yang bebas ini, suara masyarakat menjadi faktor yang utama, sehingga butuh pengenalan yang lebih dekat. Dan cara yang paling efektif adalah berkunjung ke rumah-rumah. Ini kan yang tidak ramah bagi perempuan. Dianggap tabu bagi perempuan untuk berkunjung ke rumah-rumah orang di malam hari" - (Wawancara, Alit, Politisi PDIP, 22 Juli 2019). 
Nyata bahwa politisi perempuan di Bali memiliki hambatan pada sumber daya waktu. Sumber daya waktu ini dapat dibagi menjadi dua aspek. Aspek pertama adalah waktu yang dimiliki politisi perempuan yang minim dikarenakan kewajiban mereka dalam sektor domestik atau rumah tangga, sektor publik atau ekonomi bagi yang bekerja dan sektor adat dan agama. Aspek kedua adalah waktu berpolitik yang kadang tidak ramah perempuan, di mana kegiatan-kegiatan partai kerap kali dilakukan pada waktu yang tidak ramah bagi perempuan.

\subsubsection{Sumber daya pengalaman}

Politisi perempuan di Bali memiliki kecenderungan pengalaman politik yang minim. Hal ini dikarenakan motivasi untuk berpolitik pun rendah di Bali. Perempuan yang menjadi caleg pada pemilu 2019 rata-rata adalah perempuan yang sebelumnya tidak berkecimpung di politik, dan baru dipinang oleh partai. Pinangan partai untuk mencalonkan diri semata-mata hanya demi memenuhi syarat kuota perempuan dalam daftar calon tetap.

Untuk politisi perempuan petahana, mereka memiliki kesempatan untuk belajar berpolitik. Hal ini terbukti bahwa perempuan petahana di tingkat DPRD Provinsi/Kabupaten/Kota memiliki kecenderungan terpilih kembali. Ironisnya hal ini tidak terjadi pada perempuan petahana di tingkat DPR RI. Hal ini dikarenakan dua hal yakni, pertama perempuan petahana di tingkat nasional, adalah PAW di mana masa kerja mereka belum maksimal untuk memiliki pengalaman politik yang matang. Kedua, semakin tinggi level maka sumber daya pengalaman yang dibutuhkan akan semakin besar. A.A. Astrid contohnya. Ia adalah petahana, yang telah lama berkarir politik, namun pada Pemilu 2019 ia tidak berhasil terpilih menjadi anggota legislatif di DPR RI.

"aku aktivis, dan ternyata latar belakang itu tidak cukup membantu saat masuk ke partai politik" - (Wawancara Anak Agung Istri Putri Astrid Kartika, caleg DPR RI, PDIP, 29 Maret 2019). 
Hal berbeda pada level legislatif yang lebih rendah. Pengalaman para perempuan petahana membantu mereka untuk kembali mendulang suara pada pemilu 2019. Para perempuan petahana dalam pertarungannya dibantu oleh jaringan yang telah lama berpengalaman di politik, seperti mantan bupati, mantan sekda, hingga tokoh-tokoh politik lokal. Contohnya adalah Meta dari DPRD Kota Denpasar. Pemilu 2019 adalah pemilu kedua yang diikuti, namun karena telah memiliki pengalaman di beberapa organisasi sayap partai, dia memiliki modal sosial untuk bertarung kembali.

"Pengalaman organisasi pertama kali adalah Musyawarah Kekeluargaan Gotong Royong (MKGR), Angkatan Muda Pembaruan Indonesia (AMPI) Bali, Anggota Kaukus Perempuan Politik Indonesia (KPPI) dan Anggota Komite Nasional Pemuda Indonesia (KNPI) Bali, ini cukup membantu saya" - (Wawancara Putu Metta Dewinta, Caleg DPRD Denpasar, Golkar, 26 Maret 2019).

Jadi, sumber daya pengalaman dalam pertarungan politik adalah hambatan bagi politisi perempuan yang bertarung di tingkat tertinggi yakni pada tingkat DPR RI, dikarenakan minimnya pengalaman politik yang mereka miliki. Terdapat perbedaan sumber daya pengalaman yang harus dimiliki untuk perempuan dalam bertarung di level yang berbeda.

\subsubsection{Sumber daya jaringan pendukung}

Sumber daya jaringan pendukung bagi calon legislatif perempuan di Bali merupakan sumber daya yang paling signifikan untuk mengejar karir politik. Namun sumber daya jaringan yang dimiliki perempuan di Bali memiliki keterbatasan. Jaringan sosial yang dimiliki hanya sebatas pada jaringan kekeluargaan dan atau jaringan kekerabatan. Cakupan jaringan sosial yang dimiliki pun hanya terbatas secara geografis dan kultural. Sebagian besar jaringan yang digunakan adalah jaringan bapak/suami/kerabat yang terlebih dahulu berkarier di bidang politik. Pengaruh dari jaringan ini pun terbatas pada wilayah dan kawasan tertentu seperti kabupaten 
tertentu saja tidak lintas kabupaten atau lingkup provinsi. Hal ini yang disinyalir menyebabkan terjadi peningkatan perempuan yang duduk di DPRD tingkat Provinsi dan Kabupaten namun tidak ada yang berhasil duduk di DPR RI.

NiLuhPutu Yuli, salah satu caleg perempuan dapil Karangasem untuk DPRD Provinsi dari Golkar memiliki jaringan yang kuat di daerahnya saja. Perjalanan politiknya didukung jaringan Bapak dan Pamannya, Wayan Gredeg dan Komang Kisid yang merupakan mantan pejabat di Kabupaten Karangasem. Wayan Gredeg adalah mantan Bupati kabupaten setempat yang merupakan bapak dari Yuli. Komang Kisid adalah pamannya, calon bupati Karangasem.

"Sulit apabila tatap muka dengan masyarakat umum, karena yang dilihat ya Pak Gredeg dan Pak Kisid... Di tim sukses, perempuan hampir tidak ada, Pak Gredeg lah kunci kemenangan. Yuli itu tidak bisa menari, hanya bisa menari sedikit kalau ngayah, ya mendet sih bisa"- (Wawancara Komang Kisid, Tim Sukses Ni Putu Yuli Artini, DPRD Provinsi Dapil Karangasem, Golkar, 4 April 2019).

Dwi Yustiawati, caleg dari PDIP di dapil Klungkung untuk DPRD Provinsi, mengungkapkan hal yang sama. Dwi Yustiawati berhasil mendapatkan suara terbanyak dari dapil Klungkung untuk DPRD Provinsi Bali. Ia mengakui sumber daya yang dimiliki dalam terjun berpolitik adalah sumber daya jaringan yang dimiliki suaminya berhasil meraih suara. Seperti yang diungkapkan Dwi Yustiawati di bawah ini:

"investasi sosial sudah dari dulu ke masyarakat, kalau materi kita kesusahan, jadi kita berinvestasi secara sosial." (Wawancara Ni Luh Kadek Dwi Yustiawati, Caleg DPRD Provinsi Dapil Klungkung, PDIP, 6 Mei 2019)

Suami Dwi Yustiawati adalah Ketut Leo, seorang dewan Pembina Ormas Baladika Bali, organisasi masyarakat berbasis massa yang cukup terkenal. Dengan membawa ketenaran suaminya, Dwi Yustiawati mengaku tidak memiliki hambatan untuk diterima di 
masyarakat.

"Suami saya yang didatangi oleh partai untuk ikut gabung ke partai politik. Saat kampanye tidak ada penolakan yang krusial tapi langsung diterima, mungkin sudah citranya Pak Leo sejak sebelum saya kampanye" - (Wawancara Ni Luh Kadek Dwi Yustiawati, Caleg DPRD Provinsi Dapil Klungkung, PDIP, 6 Mei 2019).

Putu Metta Dewinta Windy, caleg Golkar dari Denpasar adalah anak dari petinggi partai di tingkat daerah yang merupakan mantan Sekretaris Daerah Kabupaten Badung, Made Sutama. Ia mengatakan bahwa alasannya masuk ke politik adalah ayahnya yang mengenalkannya pada organisasi-organisasi seperti Kesatuan Perempuan Partai Golkar (KPPG) Provinsi Bali, Angkatan Muda Pembaruan Indonesia (AMPI) Bali, Musyawarah Kekeluargaan Gotong Royong (MKGR), Kaukus Perempuan Politik Indonesia, dan KNPI.

Namun, jaringan sosial yang lebih berhasil adalah jaringan sosial yang berbasis keluarga atau kekerabatan. Jaringan sosial yang berbasis partai ternyata tidak dapat maksimal digunakan oleh caleg perempuan. Hal ini disampaikan A.A. Astrid Putri, caleg PDIP untuk DPR RI. Ia mengatakan bahwa mesin partai tidak banyak membantu dalam pemilu serentak 2019, bahkan partai hanya berperan sebagai modal simbolik. Berikut pernyataan Putri:

"Ada bahasa simbolik yang kita tidak bisa jelaskan, minta bantuan massa tidak ya saya harus katakan bahwa secara simbolik keberadaan partai memberikan saya dukungan lebih kalau di lapangan apa yg dia bantu secara simbolik" - (Wawancara Anak Agung Istri Putri Astrid Kartika, caleg DPR RI, PDIP, 29 Maret 2019).

Hal ini pun membuktikan bahwa partai politik hanya memperlakukan caleg perempuan sebagai pelengkap guna memenuhi kuota sedangkan setelah ditetapkan sah oleh KPU, maka caleg perempuan ini tidak diayomi bahkan tidak diberikan bantuan dari partai politik sama sekali. 


\subsubsection{Motivasi}

Politisi perempuan di Bali terlihat memiliki kecenderungan bermotivasi rendah dalam berpolitik. Politisi perempuan di Bali tidak memiliki ambisi politik, maupun dorongan untuk berkarir di politik yang cukup tinggi. Sebagian besar perempuan yang bergabung di partai atau menjadi calon legislatif adalah perempuan yang dipinang partai untuk memenuhi kebutuhan kuota 30\%.

"ya kami makin ke bawah makin kesulitan mencari perempuan untuk dicalonkan. Jadi ya bila tidak ada di sayap partai, ya kerabat pengurus partai lalu siapa saja lah yang kira-kira mau dicalonkan" - (Wawancara I Made Gede Ray Misno, Ketua Bapilu Gerindra Bali, 6 April 2019).

"Di pemilu 2014, saya dipinang untuk memenuhi kuota perempuan saya, saya tidak terpikir untuk berkarir di partai atau politik" - (Wawancara I Gusti Ayu Diah Werdhi Srikandi W Caleg DPRD Provinsi, Dapil Jembrana, PDIP, 30 Maret 2019).

"Pada awalnya, saya dipercaya untuk membantu Partai Golkar melengkapi kuota $30 \%$ perempuan itu saja, saya tidak punya pengalaman mau pun motivasi" - (Wawancara Putu Metta Dewinta, Caleg DPRD Denpasar, Golkar, 26 Maret 2019).

"Daya juangnya juga masih belum maksimal. Susah cari calon perempuan yang benar-benar siap untuk bertarung. Daya juangnya belum seperti lakilaki. Banyak yang berpikir nyerah saja sebelum tarung. Ada yang fight seperti Ratnadi di Gianyar itu, tapi kan nggak banyak" - (Wawancara I Gusti Ngurah Jaya Negara, Sekretaris DPD PDI Perjuangan Bali, 6 Mei 2019).

Petikan wawancara di atas memperlihatkan bahwa caleg perempuan di Bali tidak memiliki ambisi yang besar dalam mengejar karir politik. Ini tercermin dari tidak adanya niat perempuan mendaftarkan diri sebagai caleg ke partai politik. Mereka justru mendapat pinangan dari partai politik. Oleh sebab itu, sebagian besar caleg perempuan menyatakan motivasi utama mereka mencalonkan diri sebatas memenuhi kuota perempuan. 


\subsection{Demand Side}

Dalam menjelaskan rendahnya keterpilihan perempuan pada pemilu 2019 di Bali, terutama untuk tingkat nasional, dapat dilihat darisudut pandang demand. Perspektif ini meletakkan titik berat pada partai politik sebagai selector. Kerangka demand ini menyebutkan, apa yang dipilih publik dalam pemilu adalah keluaran dari hasil seleksi yang dilakukan partai politik. Dalam melakukan seleksi kandidat di partai politik, menurut Norris dan Lovenduski (1995) idealnya ada proses evaluasi bakal caleg dengan melihat karakter personal, kualifikasi formal, dan pengalaman politik dari bakal caleg yang bersangkutan. Namun, sering penilaian tentang tiga hal tersebut dikaitkan dengan stereotype kelompok di mana bakal caleg menjadi bagiannya, bukan kemampuan individu kandidat. Hal ini oleh Norris dan Lovenduski disebut dengan direct discrimination. Selain itu, ada yang disebut dengan imputed discrimination. Ini berkaitan dengan apa yang diduga partai sebagai sikap pemilih terhadap latar belakang kelompok tertentu dari kandidat.

Pada konteks Bali, proses evaluasi bakal caleg berdasarkan karakter personal, kualifikasi formal dan pengalaman politik sangat tertutup di masing-masing partai. Direct discrimination yang terkait gender kandidat secara eksplisit disebutkan oleh partai politik. Berikut adalah pernyataan dua pengurus partai politik yang merupakan selector di partainya tentang calon perempuan dalam pemilu 2019.

"Kalau calon perempuan di Bali biasanya waktu terbatas. Lebih banyak urusan rumah tangga. Belum lagi jika pulang malam jadi masalah. Dua kali saja pulang di atas jam sembilan malam sudah jadi cibiran tetangga. Sedankan kerja-kerja politik seperti bertemu warga (simakrama) itu kan seringnya malam.... Isu-isu yang biasanya lebih dekat dengan kandidat perempuan itu kesehatan dan hak-hak perempuan" (Wawancara I Made Gede Ray Misno, Ketua Bapilu Gerindra Bali, 6 April 2019).

"Gerak perempuan masih terbatas. Daya juangnya juga masih belum maksimal. Susah cari calon perempuan yang benar-benar siap untuk bertarung. Daya juangnya belum seperti laki-laki. Banyak yang berpikir 
nyerah saja sebelum tarung. Ada yang fight seperti Ratnadi di Gianyar itu, tapi kan nggak banyak" (Wawancara I Gusti Ngurah Jaya Negara, Sekretaris DPD PDI Perjuangan Bali, 6 Mei 2019).

Dua pernyataan di atas memperlihatkan bahwa selector melihat kandidat berdasarkan gender-nya, bukan berdasarkan kemampuan individu yang dimilikinya. Tak satupun dari selector yang diwawancarai dalam penelitian ini menyebutkan tentang kemampuan dan pengalaman politik perempuan sebagai dasar pertimbangan pencalonan caleg perempuan. Mayoritas selector mengakui sulitnya mencari caleg perempuan karena minat perempuan mencalonkan diri sangat rendah. Oleh karenanya, partai-partai di Bali lebih sering melamar kandidat perempuan, dibanding menyeleksi kandidat perempuan yang mendaftar. Mereka yang dilamar sebagai kandidat umumnya adalah keluarga pengurus partai dan kerabat dekat dari tokoh masyarakat yang memiliki pengaruh di tingkat lokal.

“Bu Yuni dari Gianyar misalnya, yang dicari pertama itu suaminya, Pak Romo, karena suaminya kan tokoh. Itu awalnya ceritanya kan begini, kita ingin cari figur perempuan untuk mengisi peta di satu daerah, lalu kita cari ada nggak figur perempuannya. Saat kesulitan menemukannya, kita cari tokoh-tokoh di daerah itu. Kita berharap mudah-mudahan istrinya dikasih maju. Kalau sekarang biar kekuatan suami mendongkrak suaranya itu, kenyataan masih ada yang begitu" (Wawancara I Gusti Ngurah Jaya Negara, Sekretaris DPD PDI Perjuangan Bali, 6 Mei 2019).

Kutipan di atas menunjukkan bahwa proses seleksi caleg perempuan sangat longgar dan tidak berbasiskan pada tiga kriteria utama yang disebutkan sebagai kriteria ideal seleksi kandidat. Tidak mengherankan jika akhirnya partai sendiri menyadari calon perempuan yang ditawarkan sangat jauh dari ekspektasi pemilih. Hal itu karena proses kaderisasi, rekrutmen dan pendidikan politik terhadap caleg perempuan yang tidak optimal. Ini diakui oleh Badan Pemenangan Pemilu Partai Gerindra Bali, I Made Gede Rai Misno berikut ini: 
"ada istilahnya caleg perempuan potensial dan caleg perempuan pelengkap. Inisayayakinada disemuapartaikarenapendidikan politikuntukperempuan di partai sebenarnya sulit sekali. kami sadar sekali ini tugas partai, tapi khusus untuk di Bali harus saya akui ini sulit sekali jika dibanding dengan daerah lain. Maka untuk ke depannya inilah program partai yang akan dikedepankan untuk solusi dari sulitnya kader perempuan" (Wawancara I Made Gede Ray Misno, Ketua Bapilu Gerindra Bali, 6 April 2019).

Dari petikan wawancara tersebut di atas, diketahui bahwa selector membagi caleg perempuan yang telah dicalonkan dalam dua kategori utama, yaitu kategori potensial dan kategori pelengkap kuota. Pengkategorian tersebut menyiratkan bahwa parpol di Bali tidak memperlakukan calon laki-laki dan perempuan dengan setara.

Adanya direct discrimination dan tujuan sekadar memenuhi kuota perempuan menyebabkan kuantitas dan kualitas calon perempuan di Bali masih jauh dari ekspektasi para selector. Kondisi tersebut diperparah dengan imputed discrimination oleh selectors terhadap kandidat perempuan. Imputed discrimination berkaitan dengan dugaan selectors atas preferensi pilihan masyarakat. Partai politik di Bali meyakini bahwa masyarakat lebih memilih kandidat laki-laki dibandingkan kandidat perempuan.

“... pandangan masyarakat Bali yang memang belum memberikan skala prioritas kepada politisi perempuan. Secara otomatis akan mengunci ruang gerak mereka. misalkan, di satu banjar ada dua caleg, satu laki-laki dan satu lagi perempuan, secara alamiah porsi lebih besar diberikan pada lakilaki. Masyarakat sendiri lebih memberi ruang pada laki-laki dibanding perempuan" (Wawancara Oka Gunastawa, Ketua DPW Nasdem Bali, 23 April 2019).

"Perempuan yang dijagokan di Gerindra Bali ada, tapi ya harus jujur kalau jumlahnya jauh lebih kecil dibandingkan laki-laki" (Wawancara I Made Gede Ray Misno, Ketua Bapilu Gerindra Bali, 6 April 2019).

Dua petikan wawancara dari dua partai yang berbeda tersebut memperlihatkan bahwa partai-partai di Bali memandang pemilih 
memiliki preferensi yang berbeda atas gender kandidat. Partai berasumsi bahwa pemilih lebih memberi ruang pada laki-laki untuk dipilih dibandingkan perempuan. Dasar pemikiran tersebut kemudian membuat partai lebih banyak menominasikan dan memberi support pada caleg laki-laki dibanding caleg perempuan. Perbedaan dukungan partai terhadap caleg laki-laki dan perempuan diungkapkan oleh salah seorang caleg perempuan incumbent untuk level DPR RI dari PDIP yang tidak terpilih kembali, Agung Astrid, seperti pada petikan wawancara berikut ini.

"Hambatan yang saya rasakan lebih di internal ya, khususnya di ranting. Ketika (caleg) laki-laki yang meminta bantuan mereka jauh ringan tangan daripada kalau perempuan yang minta bantuan. Tidak mau membantu. Mereka (struktur partai) hanya membantu yang dirasa nyaman dengan sesamanya (laki-laki). Ada pembatasan ruang, menurut saya aneh. Caleg laki-laki diterima, dalam hal akses ke ranting (mesin partai). Sepengetahuan saya semua caleg perempuan di partai seperti itu. Solusi untukmengatasinya, akhirnya saya bersyukur saya tidak dibukakan akses di partai jadi saya bisa melihat partai dari luar. secara simbolik partai menguntungkan bagi saya"(Wawancara Anak Agung Istri Putri Astrid Kartika, caleg DPR RI, PDIP, 29 Maret 2019).

Diskriminasi yang bersumber dari internal partai dalam proses kampanye lebih dirasakan calon perempuan. Hal ini dikemukakan oleh Diah Werdhi Srikandi, Caleg DPRD Bali Dapil Jembrana dari PDIP. Ia menyebut diskriminasi diperolehnya dari elit dan masyarakat (pemilih).

"Sebenarnya di masyarakat dan elit saya dipandang sebelah mata. Jadi diragukan. Apalagi masih muda. saya aktif di partai tapi masih junior. Ketika saya PAW kemarin saya tidak menyiakan waktu dalam 3 tahun itu. saya usahakan menyelesaikan tugas saya. Saya menyandang gelar doktor dan itu justru beban sekali bagi saya. Bagaimana kita membawa diri jadi penting. Perempuan dianggap sebelah mata. Kalau kita tidak bisa membuktikan berarti kita termakan oleh stereotip tersebut."- (Wawancara I Gusti Ayu Diah Werdhi Srikandi W Caleg DPRD Provinsi, Dapil Jembrana, PDIP, 30 Maret 2019). 
Dua petikan wawancara di atas menjelaskan bahwa partai politik memberi perlakuan yang berbeda dari sisi akses terhadap mesin partai pada kandidat laki-laki dan perempuan. Diskriminasi akses calon perempuan terhadap mesin partai yang kuat di wilayah dengan identifikasi partai politik seperti Bali dapat menjelaskan fenomena rendahnya keterpilihan perempuan di Bali dan nihilnya wakil perempuan dari Dapil Bali ke DPR RI. Diskriminasi akses mesin partai diduga kuat berhubungan dengan direct dan imputed discrimination yang telah diakui oleh para selector.

Sisi demand ini memberi penjelasan atas rendahnya keterpilihan perempuan di Bali meski kuota 30\% telah dipenuhi oleh partai politik. Efek dari diskriminasi gender di partai politik baik direct maupun imputed bukan terlihat langsung pada jumlah perempuan pada daftar calon. Karena jumlah tersebut telah diatur dalam undang-undang. Efek diskriminasi itu terlihat justru dalam proses pemenangan khususnya pada akses terhadap mesin partai politik pengusung caleg tersebut. Pratiwi (2019) menegaskan bagaimana partai politik memandang perempuan dalam politik adalah hal penting, karena partai politik adalah pintu gerbang perempuan dalam politik. Cheng dan Tavits (2011) menyatakan peran partai politik menjadi penting dalam memotivasi calon legislatif perempuan untuk bertarung dalam pemilu. Cheng dan Tavits (2011) dalam risetnya menyatakan apabila perempuan minim di politik maka partai politik di tingkat tersebutlah yang ikut memiliki andil. Hal serupa diungkapkan Partini (2012) bahwa politik di Indonesia masih lemah untuk politik adil gender dan pengarusutamaan gender belum terimplementasi pada ranah politik di Indonesia.

\section{Simpulan}

Kerangka supply-demand memberikan gambaran rendahnya keterpilihan perempuan di Bali pada Pemilu 2019 dikarenakan hambatan-hambatan besar pada sisi supply dan perpaduan diskriminasi pada demand dari partai dalam hal akses serta dukungan partai. 
Pada sisi supply diketahui bahwa caleg perempuan yang bertarung di Bali pada Pemilu 2019 memiliki keterbatasan dan hambatan di berbagai sektor, (1) kemampuan finansial yang minim, (2) pengalaman politik yang sedikit, (3) jaringan sosial yang terbatas, (4) keterbatasan ruang gerak dan waktu, dan (5) rendahnya motivasi politisi perempuan dalam berkarir politik.

Pada sisi demand, atau dari perspektif bagaimana partai memilih perempuan untuk masuk ke dalam daftar caleg diketahui bahwa partai politik memberi perlakuan yang berbeda dari sisi akses terhadap mesin partai pada kandidat laki-laki dan perempuan. Efek diskriminasi itu terlihat dalam proses pemenangan khususnya pada akses mesin partai politik dan turunannya. Diskriminasi akses mesin partai diduga kuat berhubungan dengan direct dan imputed discrimination yang telah diakui oleh para selector di partai politik.

Untuk meningkatkan keterpilihan perempuan maka aspekaspek dalam kerangka pemikiran supply-demand harus ditingkatkan baik dari kapasitas caleg perempuan, sistem dan budaya di partai politik hingga aturan hukum pemilu dan partai politik yang lebih menguntungkan perempuan.

\section{Daftar Pustaka}

Amalia, Lucky Sandra. 2019. Upaya Mobilisasi Perempuan Melalui Narasi Simbolik 'Emak-Emak dan Ibu Bangsa' Pada Pemilu 2019. Jurnal Penelitian Politik Vol 16, No 1 (2019), 17-33

BaliTribune. 2019. “52 Perempuan Legislator Bali', sumber: http:// balitribune.co.id/content/52-perempuan-legislator-bali_diakses pada 17 Juli 2019

Cakra Wikara Indonesia.2018. Menyoal Data Representasi Perempuan di Lima Ranah. Depok: Cakra Wikara Indonesia

Cheng, Christine, Margit Tavits. 2011. Informal Influences in Selecting Female Political Candidates. Political Research Quarterly 64 (2) 460- 
Darma Putra, I Nyoman. 2007. Wanita Bali Tempo Doeloe Perspektif Masa Kini. Bali : Pustaka Larasan

Dewi, K. H., Kusumaningtyas, A. N., Ekawati, E., \& Soebhan, R. S. 2018. Modal, Strategi dan Jaringan Perempuan Politisi dalam Kandidasi Pilkada Langsung. Jurnal Penelitian Politik, 15(2), 267-288.

IDEA, 2002. Perempuan di Parlemen Bukan Sekedar Jumlah, Jakarta: IDEA

Interparliamentary Union. 2017. "New IPU and UN Women Map Shows Womens Representation in Politics Stagnates", sumber: https:// www.ipu.org/news/press-releases/2017-03/new-ipu-and-unwomen-map-shows-womens-representation-in-politics-stagnates diakses pada 1 Agustus 2019

Jha, Nitish. 2004. Gender and Decision Making in Balinese Agriculture. American Ethnologist, 31 (4), 552-572.

Krook, Mona Lena. 2009. Beyond Supply and Demand: A Feminist Institutionalist Theory of Candidate Selection. Political Research Quarterly, 63(4) 707-720.

Liputan6. 2018. " KPU Batal Coret 12 Bacaleg Nasdem dari Dapil Buleleng", sumber: https://www.liputan6.com/pileg/read/3627449/ kpu-batal-coret-12-bacaleg-nasdem-dari-dapil-buleleng_diakses pada 2 Agustus 2019

Manalang, Jazirah Rose. 2018. Ketimpangan Gender dalam Politik Indonesia Pasca Pemilu 2014. Analisis CSIS, 47 (1), 98-114.

Nakatani, A. 2003. Ritual as 'Work': the invisibility of women's socioeconomic and religious roles in changing Balinese society. In T. A. Reuter, Inequality, Crisis and Social Change in Indonesia (pp. 119-144). London: Routledge.

Neuman, Lawrence. 2014. Social research Method: Qualitative and Quantitative Approaches $7^{\text {th }}$ ed. UK: Pearson

Nusa Bali.com. 2019. “9 Srikandi jadi Punggawa DPRD Bali Periode 2019-2014", sumber: https://www.nusabali.com/berita/51698/9srikandi-jadi-punggawa-dprd-bali-periode-2019-2024 diakses pada 
3 Agustus 2019

Norris, Pippa dan Joni Lovenduski,. 1995. Political Recruitment: Gender, Race, and Class in the British Parliament, New York: Cambridge Univesity Press

Partini. 2012. Politik Adil Gender: Sebuah Paradoks. Jurnal Pemikiran Sosiologi. Vol 1 No.2 39-51

Perdana, Aditya, Delia Wildianti. 2019. Women Political Movements After 20 Years of Reformation in Indonesia. Jurnal Perempuan Vol 24 No. 1

Pratiwi, Andi Misbahul Pratiwi. 2019. . Kebijakan, Praktik \& Politik Keterwakilan Perempuan dalam Partai Politik: Studi Kasus Aleg Perempuan DPRD Kabupaten/Kota Periode 2014-2019. Jurnal Perempuan Vol 24 No 2, 151-163

Prastiwi, Juwita Hayyuning, Wimmy Haliim. 2018. Politisi Perempuan dan Korupsi: Mencari Solusi atas Dilema POlitik Kesetaraan Gender di Era Reformasi. Kafa'ah Journal 8 91), 2018 71-81

Razavi, Shahra. 2001. Women in Contemporary Democratization . International Journal of Politics, Culture and Society. Vol 15. No 1, 201224

Rhoads, E. 2012. Women's Political Participation in Indonesia: Decentralisation, Money Politics and Collective Memory in Bali. Journal of Current Southeast Asian Affairs, 31(2), 35-56.

Soeseno, N. 2014. Female Politicians in Political Parties of 2014 Election: Descriptive Representation vs Substantive Representation. Indonesian Feminist Journal, 4-31.

Tagar. 2019. "Daftar Caleg PDIP Terpilih jadi Anggota DPR", sumber: https://www.tagar.id/daftar-caleg-pdip-terpilih-jadi-anggota-dpr diakses pada 3 Agustus 2019

Tempo.co. 2014. "Caleg Perempuan Bali Dipaksa Berjuang Lebih Keras", sumber: http://nasional.tempo.co/read/news/2014/01/30/078549629/ caleg-perempuan-bali-dipaksa-berjuang-lebih-keras/3 diakses pada 2 Agustus 2019 
Tribunnewswiki.com. 2019. "Daftar Anggota DPR RI Daerah Pemilihan Provinsi Bali Periode 2019-2024", sumber: https://www. tribunnewswiki.com/2019/09/09/daftar-anggota-dpr-ri-dpd-ridaerah-pemilihan-provinsi-bali-periode-2019-2024 diakses pada 4 Agustus 2019 